ISSN: 1907-7262, E-ISSN: 2477-5339

Volume 10, Nomor 1, Juni 2019

http://journal.stainkudus.ac.id/index.php/yudisia/index

\title{
KEDUDUKAN DAN STRATEGI HUKUM ISLAM DALAM POSITIVISASI HUKUM DI INDONESIA
}

\author{
Muhammad Shohibul Itmam ${ }^{1}$, Luluk Sekar Liyana ${ }^{2}$ \\ Fakultas Syariah IAIN Kudus ${ }^{1}$, Mahasiswa Prodi HES ${ }^{2}$ \\ Email :shohibulitmam@gmail.com ${ }^{1}$, Email :sekarliyana@gmail.com ${ }^{2}$
}

\begin{abstract}
Islamic law in the context of its position and strategy towards national law into positive law has sparked controversial sustainability since independence until now. The various strategies and explanations about them give a special pattern to the specificity of Islamic legal thinking in Indonesia. This paper focuses on how the position and strategy of Islamic law in legal positivity in Indonesia. With the legal normative and sociological approach of jurisprudence, this paper confirms a conclusion that the position of Islamic law becomes part of the raw material of national law that can be managed in a pluralist manner in conjunction with other laws that grow in Indonesia. Plurality of Indonesian law which is a necessity to be a positive partner for Islamic law towards positivation of legal law nationally. The strategy carried out is by uniting perceptions which are the substance of the teachings of Islamic teachings in the meaning of Shari'a and fiqh in the form of values of universality that exist in Islam such as the substance of justice, honesty, equality of balance and the like. With such a position and strategy of Islamic law can provide a solution as well as a great opportunity for Indonesian Islamic law to move in to color the development of national law into positive law through the process of positivist Islamic law in Indonesia.
\end{abstract}

Key Word: Islamic Law, Position, Strategy, Positivisation, National Law

Abstrak: Hukum Islam dalam konteks kedudukan dan strateginya menuju hukum nasional menjadi hukum positif telah memantik kontroversial berkelanjutan sejak kemerdekaan hingga sekarang. Ragam strategi dan penjelasan tentangnya memberi corak khusus pada ke-khasan pemikiran hukum Islam di Indonesia.Tulisan ini fokus pada bagaimana kedudukan dan strategi hukum Islam dalam positivisasi hukum di Indonesia. Dengan pendekatan normativitas hukum dan sosiological yurisprudence tulisan ini menegaskan suatu kesimpulan bahwa kedudukan hukum Islam menjadi bagian dari bahan baku hukum nasional yang bisa dikelola secara pluralis dengan bersandingan dengan hukum-hukum lain yang tumbuh berkembang di Indonesia. Pluralitas hukum Indonesia yang merupakan keniscayaan menjadi mitra positif bagi hukum Islam menuju positivisasi hukum hukum secara nasional.Adapun strategi yang dilakukan adalah dengan menyatukan persepsi yang merupakan substansi dari ajaran ajaran Islam dalam makna 
syariat dan fiqh berupa nilai universalitas yang ada dalam Islam seperti substansi keadilan, kejujuran, persamaan keseimbangan dan sejenisnya. Dengan kedudukan dan strategi hukum Islam yang demikian dapat memberi solusi sekaligus menjadi peluang besar bagi hukum Islam Indonesia untuk merangsek masuk dalam mewarnai pembangunan hukum nasional menjadi hukum positif melalui proses positivisasi hukum Islam di Indonesia.

Kata Kunci: Hukum Islam, Kedudukan, Strategi, Positivisasi, Hukum Nasional

\section{Pendahuluan}

Diskursus seputar kedudukan dan strategi positivisasi hukum Islam di Indonesia sudah lama terjadi bahkan telah ada sejak sebelum kumandangnya kemerdekaan. Perdebatan tentang keberadaan tujuh kata pada sila pertama Pancasila misalnya yang termaktub dalam Piagam Jakarta yang berakhir dengan kompromi atas nama persatuan dan kesatuan bangsa menjadi bukti historis bahwa wacana positivisasi tetap ada dan akan terus ada seiring dinamika hukum negara dan hukum positif Indonesia.Hal demikian terjadi karena adanya potensi besar pemberlakuan hukum Islam di Indonesia, mengingat sebagian besar penduduk Indonesia yang notabene muslim ditunjang dengan sifat masif dan permisif yang dimiliki oleh masyarakat yang pluralis terhadap upaya pembaharuan hukum Islam di Indonesia secara nasional (Itmam, 2015).

Menyoal terkait pemberlakuan hukum Islam dalam konteks kedudukan dan strateginya hampir dipastikanselalu bermula dari diskursus seputar shariah dan fiqh, sebab dua istilah ini merupakan inti dari hukum Islam itu sendiri, sehingga membincangkannya merupakan sebuah keniscayaan jika ingin memahami hukum Islam. Islam mengajarkan hukum yang lengkap dalam menata kehidupan yang kompleks sehingga hukum Islam tersebut berkembang pemahamannya di antara shariah dan fiqh (Itmam, 2015).

Penjelasan tentang hukum Islam, shariah dan fiqh sesungguhnya telah banyak diberikan para pakar dan telah menjadi perbincangan sejak lama, tetapi tingkat fleksibiltas istilah ini untuk digunakan dalam ruang waktu yang berbeda telah menjadikannya sebagai istilah yang menarik untuk dibahas. Karena itu mengkaji dan membahas hukum Islam, shariah dan fiqh utamanya dalam konteks kedudukan peran dan strateginya dalam berkontribusi menambah ruang gerak wacana positivisasi hukum Islam di Indonesia (Wahid, 2014).

\section{Hukum Islam, Antara Shariah dan Fiqh}

Seorang ilmuan hukum Islam, Yahya ibn al-Laithi (W.234H) berfatwa bahwa sanksi yang harus ditempuh bagi seorang amir Andalusia yang 
berjimak dengan salah seorang isterinya pada siang hari bulan Ramadan adalah puasa dua bulan berturut-turut dan tidak boleh memilih memerdekakan hamba atau memberi makan enam puluh orang miskin, karena dua sanksi tersebut terlalu ringan baginya (Mubarak, 2000).

Narasi persoalan dan kisah tersebut dapat menggambarkan tentang bagaimana hukum Islam bisa diaplikasikan dalam bentuk berbeda tergantung pada ruang waktu, kapan dan dimana digunakan dalam menyelesaikan masalah hukum. Hukum Islam yang dalam studi barat sering disebut dengan Islamic law yang bisa jadi diartikan sama dengan shari'ah atau bahkan juga figh, namun dalam bingkai ruang waktu tertentu ketiga istilah ini juga bisa memiliki makna yang berbeda.

Taher Mahmood menggambarkan, -In those Arabic countries where French remains the second language the expressions ,statutpersonnel and code du la famille" are in official use. And in the English-speaking Islamic countries of South Asia the term "Muslim personal law" applicable to the laws of marriage, divorce, family relations, successions, wills, gift, preempation and waqfs-is widely prevalent. Interchangeably this law is also described as "Islamic law" "Muslim law", "Shari"ah", or "Shari"at". All the expression are in use also in the Muslim countries of South East Asia(Mahmood, 1987).

Selanjutnya dalam pembahasan lainnya Taher Mahmood juga menyebutkan, "As is well known, Islamic law has been known through its various versions called the madhahib "schools of law". Among the Sunni Muslims there have been the Hanafi, the Shafi"i, the Maliki and the Hanbali schools of law(Mahmood, 1987).

Tampak jelas dari deskripsi di atas bahwa Taher Mahmood ingin mempersamakan antara Islamic law dengan shariat dan shools of law atau madhahib yang di lingkungan sunni diwakili oleh Hanafi, Shafi'i, Maliki, dan Hanbalisebagaimana dipahami empat madhab ini merupakan representasi dari wacana pergumulan fiqh pada masanya.

Dalam definisi ini sekali lagi hukum Islam disamakan dengan Syariat. Shariat sendiri secara lughawy bermakna jalan ke tempat pengairan atau jalan yang asal yang diturut, atau tempat lalu air di sungai (Syarifuddin, 1999). Sedangkan menurut istilah yaitu ajaran dan aturan yang bersumber dari alQur'an dan as-Sunnah. Dalam pengertian senada Jaih Mubarok mengutip pendapat Muhammad Ismail (1999) mengaskan bahwa "apa yang telah ditetapkan oleh Allah untuk hambanya baik dalam bidang keyakinan, perbuatan maupunakhlak.Sementara Hasbi Ash Shidiqy mengutip pendapat Syaltut memberikan arti shariat untuk hukum-hukum dan aturan-aturan yang ditetapkan Allah untuk hambanya untuk diikuti dalam hubungannya dengan Allah dan hubungan manusia sesamanya” (Ash- Shiddieqy, 1975). 
Dengan demikian, yang dimaksud dengan shariat adalah peraturan yang telah ditetapkan (diwahyukan) oleh Allah kepada Nabi Muhammad SAW untuk manusia yang mencakup tiga bidang, yaitu keyakinan, perbuatan, dan akhlak (Mubarok, 1999).

Berbeda dengan pengertian di atas, bagi sebagian orientalist shariat tidak lebih dari produk akal yang mengalami dimensi perkembangan secara gradual seperti pemikiran pada umumnya. Adalah Ignaz Goldziher, dengan teori perkembangannya, yang julung kali secara panjang lebar menulis bahwasanya Hukum Islam itu mengalami perkembangan (Entwicklung: development) dan pemekaran (Entfaltung: Unfolding) dalam arti tidak langsung matang, lengkap atau tertib dari permulaan, akan tetapi melalui proses panjang dari masa pembentukan (formation), kelahiran (genesis), pertumbuhan (growth), pematangan (ossification) dan akhir-nya kemerosotan (decline) (Mubarok, 2009).

Semua itu konon terjadi akibat tuntutan zaman dan perubahan masyarakat dari masa ke masa, "...nach Massgabe des öffentlichen Bedürfnisses die gesetzliche Entwicklung des Islams gleich nach dem Tode des Propheten ihren Anfang nimmt." Teori yang menyertai pendekatan historis ini menjadi 'rukun iman' orientalisme yang digigit kuat-kuat oleh para pengkaji sezaman maupun sesudahnya -Alois Sprenger, David Samuel Margoliouth, Duncan B. Macdonald, dan E. Graf.Teori berikutnya adalah 'teori pinjaman' yang juga merupakan asas dari metode penelitian sejarah. Teori ini mengandaikan bahwasanya agama -seperti halnya pengetahuan, ketrampilan dan seni- adalah hasil budi-daya dan reka-cipta manusia. Ia tidak muncul dari langit biru, melainkan berasal dari pergaulan antar anggota masyarakat, puak atau bangsa tertentu dengan bangsa lainnya. Maka Islam pun beserta segala ajarannya disikapi sebagai bikinan manusia (bukan wahyu samawi) (Inpasonline, 2016).

Secara terminologis, fiqh merupakan disiplin keilmuan yang fokus pada hukum-hukum shara" yang bersifat praktiss amaliyah yang diderivasikan (istinbat) dari dalil-dalil yang terperinci (Tamrin, 2015). Sehingga fiqh dipahami sebagai konotasi makna hermeneutis, selain mempunyai arti sosial dan makna dalam arti hukum agama. Selain itu, dengan adanya pengaruh oleh pra-anggapan metafisik dari teologi Islam (kalam), fiqh kemudian membedakan dengan tegas antara pemahaman (understanding) dan penafsiran (interpretation) untuk memproteksi autentisitas dan kesempurnaan wahyu. Jadi figh lebih banyak diarahkan pada pemahaman makna teks dengan kaidah-kaidah yang bersifat bayaniyah, dan tidak pada tafsiran yang fungsional bagi kehidupan manusia. Pendek kata, 
fiqh adalah jendela dalam melihat fenomena sosial dalam perspektif Islam (Itmam, 2015).

Fiqh berdiri sendiri tetapi tidak keluar dan tetap berada di dalam ranah shariahdansaat menjalankan fungsinya sebagai kacamata dalam melihat fenomena sosial, ia berfungsi operatif dengan mempertimbangkan fakta-fakta sosial yang ada di sekitarnya. Artinya meminjam penjelasan dari Shohibul Itmam, shariat berlaku abadi sedangkan fiqh sangat terkait dengan ruang dan waktu. Sehingga, hukum Islam di Indonesia dapat dipahamisebagai sebuah hukum yang bersumber dari ajaran shariat Islam, yaitu al-Qur'an dan al-Sunnah yang merupakan gabungan fiqh dan shariat (Itmam, 2015). Teori ini tentu saja mengkritisi pendapat para orientalis. Bagi Alfred von Kremer, I. Goldziher, G. Bergsträsser, Joseph Schacht, G.-H. Bousquet, Judith R. Wegner, Patricia Crone, Norman Calder, Harald Motzki, Christopher Melchert, dan Wael B. Hallaq, semua orientalis ini pada intinya sebulat suara bahwasanya fiqh dan ushul fiqh sebagai suatu bangunan ilmu baru muncul pada abad kedua dan atau ketiga Hijriah, sekitar seratus hingga dua ratus tahun setelah wafatnya Nabi MuÎammad saw. Masih menurut mereka, fiqh bermula dari praktik masyarakat yang tetap terpelihara turuntemurun aliasliving traditions -istilah Schacht- yang kemudian ditulis dan dibincangkan oleh sekelompok cendekiawan hingga lama-kelamaan tersusun dan terbentuk menjadi sebuah disiplin ilmu. Hadits beserta sanadnya dicipta sebagai alat justifikasi suatu tindakan atau pendapat tertentu dalam polemik antar mazhab. Imam as-Syafi'i dinilai berjasa sebagai pengasas ushul fiqh akan tetapi juga dituduh bersalah sebagai pengunci pintu ijtihad dan penyebab kemandekan fiqh sebagimana pendapat Schacht dan para pengikutnya.

Syari'at Islam adalah hukum Islam yang berlaku abadi sepanjang masa. Sedangkan fiqh adalah perumusan konkret syari'at Islam untuk diterapkan pada suatu kasus tertentu di suatu tempat dan di suatu masa. Keduanya dapat dibedakan tetapi tidak dapat dipisahkan (Makrifah, 2016).

Jika kemudian pengertian ini digunakan untuk membaca kisah raja Andalusia di atas, maka ketentuan bahwa sanksi bagi orang yang melakukan hubungan suami isteri di siang hari bulan Ramadhan menurut shariat dapat memilih salah satu opsi, berpuasa dua bulan berturut-turut, memerdekakan budak, atau memberi makan 60 fakir miskin. Tetapi bahwa ada pertimbangan fakta sosial tertentu yang karenanya kemudian dua opsi terakhir tidak diberlakukan bagi amir Andalusia, hal itu semata-mata adalah hasil ijtihad fiqh.

Fiqh juga diidentifikasi sebagai salah satu dimensi hukum Islam, yakni produk penalaranfuqaha' terhadap shariah, yang secara empiris dijadikan hukum terapan oleh Muslim di berbagai kawasan. Hukum Islam 
mempunyai fungsi yang ganda, yaitu fungsi shariah dan fungsi fiqh. Shariah merupakan fungsi kelembagaan yang diperintahkan Allah untuk dipatuhi sepenuhnya, atau saripati petunjuk Allah untuk perseorangan dalam mengatur hubungannya dengan Allah, sesama Muslim, sesama manusia, dan dengan semua makhluk di dunia ini. Sedangkan fiqh merupakan produk daya pikir manusia. Fiqh merupakan usaha manusia yang dengan daya intelektualnya mencoba menafsirkan penerapan prinsip-prinsip syari'ah secara sistematis (Bisri, 2004).

\section{Kedudukan Hukum Islamdalam Konteks Positivisasi Hukum}

Positivisasi hukum Islam dapat diberi pengertian sebagai upaya untuk menjadikan hukum Islam sebagai hukum positif di Indonesia. Positivisasimerupakan upaya pembaharuan hukum nasional dengan cara menyusun grand design, menempatkan beragam nilai yang tumbuh berkembang di Indonesia sesuai dengan tuntutan pembangunan hukum nasional dan nilai hukum Islam sebagai hukum agama yang dipeluk masyoritas penduduk Indonesia (Itmam, 2015).

Shariat sendiri, sesungguhnya bertujuan demi kemaslahatan kehidupan manusia yang dalam konsep ajaran Islam terangkum dalam lima tujuan Agama atau lazim disebut al-maqasid al-khamsah atau maqasid alshariah, yaitu menjaga agama, menjaga jiwa, menjaga akal, memelihara nasab, dan menjaga harta. Sehingga ruh dari positivisasi sesungguhnya tidak hanya terfokus pada kepentingan kita sebagai sebuah bangsa tetapi juga bersinggungan kepentingan kita sebagai hamba Allah yang memiliki kewajiban untuk menegakkan agama dengan memperjuangkan lima tujuan agama dimaksud.

Ada beberapa alasan historis dan sosial yang setidaknya dapat memberi ruang bagi upaya pembaharuan kedudukan hukum Islam di Indonesia :

Pertama, bahwa bangsa Indonesia yang memiliki akar sosio kultural yang cenderung reseptif dan permisif terhadap budaya dari luar. Fakta historis tentang masuknya Islam di tanah air dan berkembangnya nilai-nilai baik timur maupun barat dari dulu hingga kini merupakan bukti yang tak terbantahkan dari sikap reseptif dan permisif masyarakat.

Kedua, bahwa ada kesadaran yang tumbuh di kalangan masyarakat hukum bahwa hukum yang berlaku di Indonesia saat ini, menurut Arifin, adalah hukum hasil politisasi hukum Belanda dengan rekayasa hukum ilmiah melalui teori Recepcio in Complexu. Dengan demikian dapat diterima bahwa positivisasi hukum Islam sebagai bentuk pengejawantahan hukum yang diberlakukan sesuai kesadaran hukum nasional serta kondisi masyarakat yang membutuhkan reformulasi hukum nasional sesuai kondisi dan kareakter 
Indonesia yang pluralis kebhinnekaan melalui legislasi negara dengan stakeholder terkait.

Ketiga, penduduk Indonesia yang sebagian besarnya beragama Islam juga merupakan potensi besar bagi upaya positivisasi hukum Islam. Realitas empirik telah membuktikan bahwa, meskipun bukannya tanpa tantangan, lahirnya regulasi-regulasi 'berbau keislaman' seperti UU Perkawinan, UU Zakat, KHI dan lain sebagainya telah mendapatkan sambutan luar biasa dari masyarakat.

Shariat dan fiqh sebagai representasi hukum Islam dengan fleksibilitasnya terhadap realitas ruang dan waktu diyakini akan mampu memberikan kontribusi positif bagi dinamika hukum dalam rangka menjawab persoalan yang terus berkembang seiring dinamika zaman yang tak akan pernah berhenti. Kedudukan Shariat dan fiqh menjadi sangat penting sebab ia akan menjadi sumber daya pokok yang dapat dieksplorasi secara maksimal untuk mengais sebesar-besar manfaat bagi umat manusia (Wahid, 2014).

Tentu tidak dapat dipungkiri bahwa dalam realitas diskursus positivisasi hukum Islam di Indonesia, seringkali dibenturkan pada keberagaman fiqh sebagai salah satu kendala dalam penerapannya, namun ketika pengertian dan pemahaman fiqh ini sudah didudukkan pada tempatnya secara proporsional semestinya tidak ada lagi polemik, sebab sekali lagi fiqh adalah dinamis dan dapat dinegoisasikan dengan ruang dan waktu di mana ia akan diberlakukan (Makrufah, 2016).

\section{Strategi dan Formulasi Hukum Islam dalam Hukum Nasional}

Dalam konteks ke-Indonesiaan sebagai konsekuensi dari negara pluralis, kebinekaan, maka salah satu dampaknya adalah maraknya cara atau sudut pandang dalam melihat agama, khusunya terhadap agama-hukum Islam. Fenomena demikian nampaknya dapat dibenarkan, antara lain dengan mengamati perkembangan studi ilmu hukum Indonesia dan hukum Islam di Indonesia yang sangat rentan dengan perbedaan serta konflik dari masa ke masa.Tarik ulur kepentingan politik dalam pergumulan hukum Islam dan hukum nasional Indonesia membentuk satu pendapat yang fokus pada nilai universalitas dalam Islam (Itmam, 2013). Sementara Ratno Lukito sebagai pakar hukum Indonesia menjelaskan bahwa hukum Islam di Indonesia telah sampai pada persoalan positivisme yang dipahami sebagai upaya menjadikan nilai-nilai ajaran Islam selaras dengan beragam nilai-nilai lain yang berkembang di Indonesia menyatu secara integral sebagai bagian dari pembangunan sistem hukum nasional melalui transformasi pluralitas nilai ke dalam hukum nasional tanpa mengorbankan hukum atau nilai tertentu. Menurutnya upaya tersebut perlu penyatuan persepsi antara hukum sakral dan hukum sekuler (Lukito, 2012). 
Ahmad Qodri Azizy mengembangkan pemikiran hukum Islam dengan teori eklektisisme (suatu sistem agama atau filsafat) yang dibentuk secara kritis dengan memilih dari berbagai sumber dan doktrin sebagai upaya reformulai hukum Islam Indonesia.Argumentasinya dengan memberikan contoh pada regulasi Kompilasi Hukum Islam (KHI) sebagai produk hukum nasional dari segi bahasa dan substansi masih menimbulkan ragam pemahaman.Orientasinya tidak bisa dipisahkan dengan gagasan pergumulan politik nasional dengan hukum Islam dengan meniadakan dikotomi antara ilmu hukum nasional dengan ilmu hukum Islam Indonesia (Azizy, 2003).

Dari sudut berbeda, Ahmad Syafi'i Maarif menjelaskan perkembangan penjajahan Belanda yang berhasil mengambil alih seluruh kekuasaan kerajaan Islam di Indonesia telah mengakibatkan sedikit demi sedikit hukum Islam terpangkas, sampai akhirnya yang tertinggalselain ibadahhanya sebagian dari hukum keluarga (nikah, talak, rujuk, waris) dengan Pengadilan Agama sebagai pelaksananya sehingga diperlukan reorientasi sesuai pluralitas hukum di Indonesia. Menurutnya diperlukan langkah strategis dengan membangun budaya hukum yang selaras dengan pluralitas hukum yang berkembang di Indonesia (Maarif, 2009).

Sementara Gunaryo menjelaskan bahwa sejarah panjang pergumulan politik hukum Islam telah membuktikan eksisnya hukum Islam di Nusantara yang idak bisa dilepaskan dari pemahaman yang sesuai dengan budaya. Menurutnya, penyesuaian hukum Islam dengan ragam budaya bisa dijelaskan antara lain dengan membangun rekonsiliasi hukum yang akomodatif terhadap dinamika hukum Islam sehingga melalui rekonsiliasi hukum Islam dengan hukum nasional tersebut dapat terbentuk hukum nasional yang sesungguhnya (Gunaryo, 2006).

Dari beragam pendapat di atas menegaskan bahwa pergumulan hukum Islam Indonesia merupakan suatu bentuk pergumulan politik hukum nasional terkait pengembangan kajian hukum Islam mengenai alDinSyari"ahFiqh yang memang sangat dibutuhkan seiring berkembangnya sosial budaya Indonesia dengan mengemas studi fiqh dengan bahasa hukum modern. Hal tersebut juga sebagai upaya meluruskan persepsi tentang syari'at melalui Pengadilan Agama terutama para hakim-hakimnya, mengakrabkan umat Islam (ulama-ulama) dengan yurisprudensi, dan membuat kompilasi hukum Islam serta perundangan sesuai dengan kebutuhan bangsa Indonesia dengan sosial budayanya (Arifin, 1996).

Dari paparan terkait hukum Islam dipahami bahwa Shariah memiliki pengertian yang lebih umum dari fiqh. Shariah meliputi seluruh ajaran Islam yang ditetapkan oleh Allah baik dalam bidang keyakinan (i"tiqadiyah), perbuatan, maupun akhlak, sedangkan fiqh lebih memfokuskan pembahasan pada persoalan yang bersifat amaly (perbuatan mukallaf). Shariah Islam adalah hukum Islam yang berlaku abadi sepanjang masa. Sedangkan fiqh 
adalah perumusan konkret syari'at Islam untuk diterapkan pada suatu kasus tertentu di suatu tempat dan di suatu masa. Keduanya dapat dibedakan tetapi tidak dapat dipisahkan. Fiqh juga merupakan produk penalaran fuqaha terhadap syari'ah, yang secara empiris dijadikan hukum terapan oleh Muslim di berbagai kawasan.

Shariat dan fiqh sebagai representasi hukum Islam dengan fleksibilitasnya terhadap realitas ruang dan waktu diyakini akan mampu memberikan kontribusi positif bagi dinamika hukum dalam rangka menjawab persoalan yang terus berkembang seiring dinamika zaman yang tak akan pernah berhenti. Dengan demikian kedudukan Shariat dan fiqh menjadi sangat penting sebab ia akan menjadi sumber daya yang dapat dieksplorasi secara maksimal untuk mengais sebesar-besar kemanfaatan bagi manusia. Dalam konteks inilah positivisasi hukum Islam sebagai representasi dari shariat dan fiqh sangat mungkin untuk diberlakukan kapanpun dan di mana pun, termasuk positivisasi hukum Islam di Indonesia.

\section{Kedudukan dan Strategi Hukum Islam Dalam Positivisasi Hukum Di Indonesia}

Diskursus tentang kedudukan dan strategi hukum islam dalam positivisasi hukum di Indonesia selalu terkait dengan masalah pergumulan hukum Islam dalam politik hukum era reformasi merupakan upaya pembangunan hukum demi terwujudnya hukum nasional yang sesuai kepentingan nasional, dengan penyusunan materi hukum secara menyeluruh bersumber pada Pancasila dan Undang-Undang Dasar Negara Republik Indonesia Tahun 1945 dengan spirit Islam. Karena itu, penyusunan Program Legislasi Nasional merupakan upaya pergantian peraturan perundangundangan yang bersumber Pancasila dan Undang-Undang Dasar Negara Republik Indonesia Tahun 1945dan merupakan upaya cerdas dalam mewujudkan hukum yang dijiwai oleh nilai-nilai nasional dan keagamaan bangsa Indonesia. Kedudukan hukum Islam menegaskan nilai hukum Islam sebagai nilai mayoritas di Indonesia berdasarkan politik hukum era reformasi mempunyai peluang besar dalam konteks pembangunan demokrasi pancasila melalui pendekatan akademik keilmuan.

Berdasarkan kedudukanya, hukum Islam memiliki prospek yang cerah karena memiliki karakter hukumresponsif. Sistem hukum Barat/kolonial sudah tidak berkembang, jumlah penduduk mayoritas beragama Islam, politik pemerintah mendukung berkembangan hukum Islam, dan hukum Islam menjadi salah satu sumber bahan baku dalam pembentukan hukum nasionaldi samping hukum adat dan hukum Barat/kolonial. Berangkat dari kerangka pikir demikian, maka strategi hukum Islam secara sederhana dapat dijelaskan bahwa Negara tidak dapat membuat hukum yang mewajibkan 
(memberlakukan)hukum agama tertentu, tetapi negara dapat membuat aturan yangmengaturpelaksanaan hukum agama yang telah dilaksanakan atas kesadarannya sendiri oleh para penganutnya. Sehingga hukum-hukumyang dibuat negara atas dasar agama berdasar terbatas padamelayanidan melindungi atas kesadaran yang tumbuh sendiri daripemeluknya agar tidak terjadi konflik diantara umat beragama.

Selain itu asas kebinnekaan di Indonesia serta era reformasi sesuai perkembangan politik hukum nasional dan juga Undang-Undang Nomor 12 Tahun 2011 tentang Pembentukan Perundang-Undangan menegaskan bahwa kedudukan Peraturan Daerah (Perda) misalnya, sangat kuat sejalan dengan pemberian kedudukan kepada kepala daerah. Perlu dicatat bahwa Orde Baru secara substantif sebenarnya tidak ada otonomi daerah, tetapi desentralisasi yang sentralistis. Daerah tidak dapatmenentukan kepala daerahnya sendiri secara demokratis, DPRD dijadikan subordinasi pemerintah daerah, kekayaan ekonomi daerah disedot habis untuk kepentingan politik pusat. Sedangkan reformasisemua sudah ditata ulang sesuai dengan semangat demokratisasi.Otonomi luas yang kemudian dianut dalam UU No. 22 tahun 2009untuk kemudian semangat ini diperkuat dengan masuknya otonomiluas dalam amandemen atas Pasal 18 UUD 1945, bahkan otonomiluas yang menekankan pada demokratisasi diperkuat dengan lahirnya UU No. 32 Tahun 2004 dan dikuti UU No. 22 Tahun 2009 tentang Pemerintahan Daerah.

Sedangkan dalam konteks strategi hukum Islam, pakar hukum sepakat bahwa agama secara politik mempunyai peran penting dalam perubahan sosial masyarakat.Peran tersebut terutama sebagai faktor penyatu integrator bagi tatanan kehidupan berdasarkan kehendak mayoritas.Peran agama dalam menciptakan ikatan bersama, baik di antara anggota-anggota beberapa masyarakat maupun dalam kewajiban-kewajiban sosial yang membantu mempersatukan kepentingan mereka sangat menentukan politik. Selain itu nilai-nilai yang mendasari sistem-sistem kewajiban sosial bersama kelompokkelompok keagamaan perlu diakomodir sehingga agama menjamin konsensus menuju kesatuan politik. Argumentasi ini semakin diperkuat dengan konsep sakral berupa nilai- nilai keagamaan sehingga agama tidak mudah digoyang, dirubah karena memiliki otoritas yang kuat di tengah sosial masyarakat.

Secara sosiologis, agama juga mempunyai pengaruh besar dalam perubahan suatu masyarakat.Agama bisa menjadi penyatuatau sebaliknya dalam konteks pembangunan sosial masyarakat. Dalam konteks positivisasi hukum Islam, nampak bahwa nilaiagama memiliki peran yang urgen tidak hanya bagi individu tetapi sekaligus bagi masyarakat. Bagi individu, agama berperan dalam mengidentifikasikan individu dengan kelompok, menghibur ketika dilanda kecewa, memperkuat moral, dan menyediakan unsur-unsur identitas. Sedangkan bagi kehidupan bermasyarakat, agama berfungsi menguatkan kesatuan dan stabilitas. 
Dengan demikian kedudukan dan strategi hukum Islam merupakan salah satu persoalan yang sangat penting dalam pembangunan hukum Islam dan perkembangan pemikiran yang terjadi antarafilsafat dan agama-hukum Islam, karena keduanya terkait perkembangan metode dan makna ijtihad yang kemudian menjadi fiqhsecara aktual yang bersifat transformatif dan akomodatif terhadap dinamika sosial di Indonesia. Pemikiran yang berkembang sangat dipengaruhi beberapa faktor yang saling berkelindan, kait mengaitantara keyakinan agama dan pemikiran/rasionalisasi terhadap perkembangan sosial masyarakat Indonesia yang terus mengalami perkembangan termasuk hukum Islam sebagai upaya positivisasi. Selain itu perdebatan pemikiran seputar hukum Islam yang mana,dengan ijtihad dan metode seperti apa juga sangat mempengaruhi terhadap upaya transformasi hukum Islam di Indonesia sesuai politik hukum nasional yang akomodatif terhadap aspirasi dan kebutuhan masyarakat khususnya sesuai amanat UU No. 12 Tahun 2011 tentang Pembentukan Peraturan Perundang-Undangan yang menegaskan perlunya aspirasi dan kebutuhan hukum masyarakat sesuai dengan kedudukan dan strategi hukum islam di Indonesia.

\section{Kesimpulan}

Kedudukan dan strategi hukum Islam menuju hukum nasional serta menjadi hukum positif penuh tantangan dan perjuangan berat dan tentu memantik kontroversial secara berkelanjutan dari masa ke-masa. Potret kedudukan hukum Islam ragam strateginya serta penjelasan tentang hukum Islam Indonesia memberi corak khusus pada pemikiran hukum Islam di Indonesia. Kedudukan hukum Islam menjadi bagian dari bahan baku hukum nasional bisa dikelola secara pluralis kebinnekaandengan bersandingan dengan hukum lain yang tumbuh berkembang di Indonesia. Pluralitas hukum Indonesia yang merupakan keniscayaan menjadi mitra yang positif saling melengkapi bagi hukum Islam menuju positivisasi hukum hukum secara nasional.Adapun strategi yang dilakukan hukum Islam adalah menyatukan persepsi terutama bidang fiqh yang merupakan substansi dari ajaran ajaran Islam berupa nilai universalitas kemanusiaan yang ada dalam Islam seperti 
keadilan, kejujuran, persamaan keseimbangan dan sejenisnya. Dengan kedudukan dan strategi hukum Islam demikian dapat memberi sekaligus menjadi peluang besar bagi hukum Islam Indonesia untuk merangsek masuk dalam mewarnai pembangunan hukum nasional melalui proses positivisasi hukum Islam di Indonesia.

\section{DAFTAR PUSTAKA}

Arifin, Busthanul. 1996, Pelembagaan Hukum Islam di Indonesia Akar SejarahHambatan dan Prospeknya, Jakarta: Gema Insani Press.

Ash-Shiddieqy, Hasbi. 1975, Filsafat Hukum Islam, Jakarta: Bulan Bintang.

Azizy, A. Qodri. 2003, Eklektisisme Hukum Islam, Kompetisi Hukum Islam dan Hukum Umum, Jakarta: Gama Media.

Bisri, Cik Hasan. 2004, Pilar-Pilar Penelitian Hukum Islam Dan Pranata Sosial, Jakarta: RajaGrafindo Persada.

Bisri, Cik Hasan. 2004, Pilar-Pilar Penelitian Hukum Islam Dan Pranata Sosial, Jakarta: Raja Grafindo Persada.

Gunaro, Ahmad. 2008, Pergumulan Politik dan Hukum Islam, Jogyakarta: PustakaPelajar kerjasama pasca sarjana IAIN Walisongo.

http://inpasonline.com/new/studi-fiqh-a-syariat-islam/, diakses pada 13 Juni 2016, 08:51

https://wikiislam.net/wiki/Islamic_Law, didownload pada tanggal 27-032016: 19:51

Itmam, M. Shohibul.2013, "Hukum Islam dalam Pergumulan Politik Hukum Nasional Era Reformasi, Jurnal al- Tahrir IAIN Ponorogo.

M. Shohibul. 2015, Positivisasi Hukum Islam di Indonesia,Ponorogo: STAIN Ponorogo Press.

Ma'arifah, Nurul. 2016, Ushul Figh danTipologi Penelitian Hukum Islam, dalam http://www.stainmetro.ac.id/ejournal/index.php/istinbath/article/view/467, didownload pada 28-032016, 11:13 
Kedudukan Dan Strategi Hukum Islam

Maarif, Ahmad Syafii.1996, Islam dan Politik: Teori Belah Bambu Masa DemokrasiTerpimpin (1959-1965), Jakarta: Gema Insani Press.

Maarif, Ahmad Syafii. 2009, Islam Dalam Bingkai Keindonesiaan dan Kemanusiaan: Sebuah RefleksiSejarah, Bandung: Mizan.

Mubarok, Jaih. 2000,Sejarah dan Perkembangan Hukum Islam, Bandung: Remaja Rosda Karya.

Mubarok, Muhammad Ismail dan Jaih Mubarok. 2003, Sejarah dan Perkembangan Hukum Islam, Bandung: Remaja Rosda Karya.

Ratno Lukito, Ratno, 2012, Hukum Sakral dan Hukum Sekuler: Studi Tentang Konflik danResolusi dalam Sistem Hukum Indonesia, Jakarta: Alvabet

Syah, Ismail Muhammad (ed). 1999, Filsafat Hukum Islam, Jakarta: Bumi Aksara.

Syarifuddin, Amirdalam Ismail Muhammad Syah (ed). 1999, Filsafat Hukum Islam, Jakarta: Bumi Aksara.

Taher, Mahmood. 1987, Personal Law in Islamic Countries, New Delhi: Academy of Law and Religion.

Tamrin, Dahlan Tamrin dalam M. Shohibul Itmam. 2015,Positivisasi Hukum Islam di Indonesia, Ponorogo: STAIN Ponorogo Press.

Wahid, Marzuki. 2014. Fiqh Indonesia: Kompilasi Hukum Islam Dan Counter Legal Draft Kompilasi Hukum Islam Dalam Bingkai Politik Hukum Indonesia. Bandung: Penerbit Marja. 